\title{
Assessment of genetic variation for pathogen-specific mastitis resistance in Valle del Belice dairy sheep
}

\author{
Marco Tolone ${ }^{1 *}$, Cristian Larrondo ${ }^{2 \dagger}$, José M. Yáñez ${ }^{2}$, Scott Newman ${ }^{3}$, Maria Teresa Sardina \\ and Baldassare Portolano'
}

\begin{abstract}
Background: Mastitis resistance is a complex and multifactorial trait, and its expression depends on both genetic and environmental factors, including infection pressure. The objective of this research was to determine the genetic basis of mastitis resistance to specific pathogens using a repeatability threshold probit animal model.

Results: The most prevalent isolated pathogens were coagulase-negative staphylococci (CNS); $39 \%$ of records and $77 \%$ of the animals infected at least one time in the whole period of study. There was significant genetic variation only for Streptococci (STR). In addition, there was a positive genetic correlation between STR and all pathogens together (ALL) $(0.36 \pm 0.22)$, and CNS and ALL $(0.92 \pm 0.04)$.

Conclusion: The results of our study support the presence of significant genetic variation for mastitis caused by Streptococci and suggest the importance of discriminating between different pathogens causing mastitis due to the fact that they most likely influence different genetic traits. Low heritabilities for pathogen specific-mastitis resistance may be considered when including bacteriological status as a measure of mastitis presence to implement breeding strategies for improving udder health in dairy ewes.
\end{abstract}

Keywords: Ewes, Mastitis, Pathogen, Resistance

\section{Background}

Mastitis is one of the most common diseases affecting dairy sheep. Mastitis leads to major economic losses, mainly due to discarded milk, reduced milk production and quality, alteration of cheese-making properties, early culling, and increased health care costs [1-8]. The alterations or reductions of the dry matter of milk and its composition, have a substantial effect on the economic and industrial values of the milk, considering that almost all is processed into fermented products and cheeses $[4,9,10]$. Mastitis resistance is a complex and multifactorial trait, and its expression depends on both genetic and environmental factors, including infection pressure. In the broadest sense, resistance could be defined as the ability to avoid any infection and/or the quick recovery

\footnotetext{
* Correspondence: marco.tolone@unipa.it

${ }^{\dagger}$ Equal contributors

'Dipartimento Scienze Agrarie e Forestali, Università degli Studi di Palermo,

Viale delle Scienze, Palermo 90128, Italy

Full list of author information is available at the end of the article
}

from an infection [11, 12], and involves different factors such as to avoid entry of the pathogen into the mammary gland, to induce an immune response capable of limiting pathogen development in the udder and to recover from the infection, as well as controlling the pathogenic effects of the infection, such as tissue damage [13].

Over 100 different micro-organisms can cause mastitis, in particular coliform bacteria, staphylococci and streptococci [14]. In dairy sheep the most important agents involved in clinical mastitis are the bacterial infections, and the most frequently isolated pathogens are coagulase-negative staphylococci (CNS); that are present on and around the udder skin [9] with a different pathogenicity causing clinical and subclinical mastitis [15-18]. The bacterial pathogens responsible for infection of the mammary gland may be grouped into two main categories: major and minor pathogens. Major pathogen infection generally results in clinical illness or strong inflammatory 
responses and reduced milk yields, whereas minor pathogen infection is usually subclinical [19].

Selection for genetic resistance to mastitis can be done directly or indirectly. Direct selection corresponds to the diagnosis of the infection: the actual trait [i.e., bacteriological examination of milk and/or observation of clinical cases of mastitis] is measured on the animal or its relatives. Indirect selection corresponds to a prediction of the bacteriological status of the udder based on traits related to the infection [e.g., inflammatory parameters]: an indicator trait for mastitis is measured on the animal itself or its relatives [20]. Simple and indirect methods have been widely applied based on the evaluation of the degree of inflammation or of internal mammary lesions [21]. Their accuracy was established by bacteriological analysis as a reference method [17]. Among the indirect methods, the most frequently used to detect mastitis are milk somatic cell count (SCC). SCC is considered as a good measure to indirectly select for mastitis resistance in cattle, especially when a direct measure of clinical mastitis incidence is not available [18, 22]. In cattle, values of SCC between 250 and $300 \times 10^{3}$ cells $/ \mathrm{mL}$ are recommended as satisfactory discrimination thresholds to distinguish between healthy and infected udders. In sheep there is no widely accepted threshold $[15,23]$ but some studies suggested a critical limit of $500 \times 10^{3}$ cells/ $\mathrm{mL}$ [24]. There are few studies concerning genetic variation of mastitis in sheep according to bacteriological status [22, 25]. A genetic selection approach could be one of the strategies for controlling mastitis and has been shown to be a valid option, together with management, to prevent mastitis cases $[1,26]$. Studies have reported genetic variation accounting for resistance to mastitis in Valle del Belice dairy sheep [22, 24]. These authors have defined mastitis as a binary trait distinguishing between ewes with at least one case of mastitis (1) and ewes without (0) in a defined period of lactation and was analyzed using a linear model approach. This definition excluded alternative definitions, for example multiple cases of mastitis within lactation, and ignored the etiology of intra-mammary infections. The purpose of this study was to determine the genetic bases of pathogen-specific resistance to mastitis in Valle del Belice dairy sheep using a threshold repeated model.

\section{Methods}

\section{Data}

Data were collected between 2006 and 2011 in five Valle del Belice flocks, with a total of 2350 ewes and 5856 animals in the pedigree. Observations for this study included 1795 primiparous, 1285 secondiparous and 2225 multiparous dairy ewes. All ewes were milked twice daily (morning and evening), and records for milk yield (MY), bacteriological status (infected or not infected), and SCC were collected at approximately monthly intervals, following an A4 recording scheme (monthly records with two daily milking) which is defined by the International Committee for Animal Recording [27]. The milk samples were collected during routine milking so avoiding any harmful process to individuals. The consent for sample collection was obtained by the animals' owners. Moreover, Sample collection, animal management and cares were in agreement with the Directive 2010/63/EU. The observed bacteriological colonies were identified as: Escherichia coli (ESCCL), Staphylococcus aureus (STHAU), Streptococcus dysgalactiae (STPDG), Streptococcus uberis (STPUB), Streptococcus agalactiae (STPAG) and Bacillus spp. (BACIL), Corynebacterium spp. (CORLT), Pasteurella spp. (PASCL), Pseudomonas spp. (PSELT), coagulase negative staphylococci (CNS) and Streptococcus spp. (STR). Ewes were considered infected if at least one record with positive bacteriological test during lactation period was recorded, while they were considered healthy if the bacteriological test did not show a positive result. Ewes were measured more than one time during the same lactation. Thus, the repeatability of records is across and within lactations. Table 1 shows average number of records per ewe within lactations. Moreover, ewes were considered infected if more than five colony forming units (CFU) per $10 \mu \mathrm{l}$ of milk of one species of bacteria were isolated. The response variable used in the model corresponds to the binary disease status, coded as 0 or 1 to represent uninfected or infected individuals, respectively.

\section{Trait definition and statistical model}

Phenotypic observations of infection status were defined as a repeated binary trait. The binary trait distinguished between sheep with infected udder status (1) and uninfected udder status (0) within each lactation for each particular pathogen described above. SCC was also recorded and normalized through a logarithmic transformation into somatic cell score (SCS) according to the formula of Ali and Shook [28]:

$$
\begin{aligned}
\text { Somatic cell score }(\mathrm{SCS})= & \log _{2}(\mathrm{SCC} / 100,000) \\
& +3
\end{aligned}
$$

Table 1 Mean, standard deviation (SD), minimum (Min) and maximum (Max) number of records per ewe within lactation

\begin{tabular}{lllll}
\hline Lactation & Mean & SD & Min & Max \\
\hline 1 & 3.47 & 1.97 & 1 & 12 \\
2 & 4.13 & 2.25 & 1 & 20 \\
3 & 4.46 & 2.33 & 1 & 15 \\
4 & 4.75 & 2.4 & 1 & 12 \\
5 & 7.47 & 5.75 & 1 & 32 \\
\hline
\end{tabular}


The binary trait was analyzed using the following repeatability threshold probit animal model:

$$
\operatorname{Pr}\left(Y_{i j k l m n}\right)=\Phi\left(\mu+O P_{i}+M Y_{j}+F Y S_{l}+P E_{m}+A_{n}\right)
$$

Where $y_{i j k l m n}$ is the observation for the specific pathogen causing mastitis (CNS, STR, ESCCL, STHAU, STPDG, STPUB, STPAG, BACIL, CORLT, PASCL, PSELT and $\mathrm{ALL}) ; \Phi$ is the normal cumulative density function; $\mu$ is the fixed effect of the overall mean; $O P_{i}$ is the order of parity fitted as fixed effect (with 5 classes); $M Y_{j}$ is the milk production yield fitted as covariate; $F Y S_{l}$ is the flockyear-season random effect (51 classes); $P E_{m}$ is the random permanent environmental effect of the individual $m$ across lactations (2350 levels with records); and $A_{n}$ is the random animal effect (5856 levels in the pedigree). The implicit residual variance on the underlying scale is 1 for the probit model (standard normal). Parameters of the univariate threshold models were estimated using ASREML version 3.0 [29].

\section{Heritabilities}

Heritabilities for resistance to different pathogens were calculated as:

$$
\boldsymbol{h}^{2}=\frac{\sigma_{a}^{2}}{\sigma_{a}^{2}+\sigma_{F Y S}^{2}+\sigma_{P E}^{2}+\sigma_{e}^{2}}
$$

Where $\sigma_{a}^{2}$ is the animal additive genetic variance, $\sigma_{F Y S}^{2}$ is the variance associated with flock-year-season, $\sigma_{P E}^{2}$ is the variance due to permanent environment and $\sigma_{e}^{2}$ is residual variance. For all traits, the animal effect was assumed $\sim \mathbf{N}\left(0, \mathbf{A} \sigma_{a}^{2}\right)$, where $\mathbf{A}$ is the additive genetic relationship matrix among all animals included in the pedigree (5856). Similarly, FYS and PE effects were assumed $\sim \mathbf{N}\left(0, \mathbf{I} \sigma_{F Y S}^{2}\right)$ and $\sim \mathbf{N}\left(0, \mathbf{I} \sigma_{P E}^{2}\right)$, where $\mathbf{I}$ is an identity matrix with order equal to number of FYS and PE classes (51 and 2350) respectively.

\section{Results}

Arithmetic mean and standard deviation of MY, SCC and SCS, for infection status (infected and uninfected) of udders are shown in Table 2. Daily average MY values were $1275 \pm 544$ and $1338 \pm 558 \mathrm{~g}$, for infected and uninfected udders, respectively. Mean SCC was $2908 \pm 4926$ and $1155 \pm 3083$ ( $\mathrm{x} 10^{3}$ cells $/ \mathrm{mL}$ ), for infected and uninfected udders, respectively; whereas mean SCS was $6.21 \pm 2.45$ and $4.55 \pm 2.13$. Overall mean values for both infected and uninfected udders were $1314 \pm$ $553 \mathrm{~g}, 1815 \pm 3972$ (x $10^{3}$ cells $/ \mathrm{mL}$ ), and $5.18 \pm 2.3$, for MY, SCC and SCS, respectively.

There was a low prevalence of isolation due to CORLT, ESCCL, PASCL, PSELT, STPDG, STPUB, STPAG, and BACIL, in all the observations and according to infection status of animals. Models did not converge for
Table 2 Arithmetic mean and SD for MY, SCC, and SCS of

\begin{tabular}{|c|c|c|c|c|}
\hline & \multirow[t]{2}{*}{$n$} & \multirow{2}{*}{$\begin{array}{l}M Y(g) \\
\text { Mean } \pm S D\end{array}$} & \multirow{2}{*}{$\begin{array}{l}\operatorname{SCC}\left(\times 10^{3}\right)^{a} \\
\text { Mean } \pm S D\end{array}$} & \multirow{2}{*}{$\begin{array}{l}\text { SCS } \\
\text { Mean } \pm \text { SD }\end{array}$} \\
\hline & & & & \\
\hline Infected & 8019 & $1275 \pm 544$ & $2908 \pm 4926$ & $6.21 \pm 2.45$ \\
\hline Not infected & 13,246 & $1338 \pm 558$ & $1155 \pm 3083$ & $4.55 \pm 2.13$ \\
\hline All & 21,265 & $1314 \pm 553$ & $1815 \pm 3972$ & $5.18 \pm 2.33$ \\
\hline
\end{tabular}
infected and uninfected udders

these pathogens, most likely due to the low incidence (zero inflation).

Absolute (AF) and relative (RF) frequency distribution according to infection status (infected or uninfected) observations within all the records data set, are shown in Table 3. The most prevalent isolated pathogens were CNS with 7951 (39\%) observations, followed by STHAU (940; $5 \%$ ) and STR (541; 3 \%). Considering all pathogens (ALL), 8019 (38 \%) milk samples were infected.

Table 4 shows absolute (AF) and relative (RF) frequency distributions according to udder status (infected or uninfected) of animals per pathogen. Similarly, the most prevalent isolated pathogens affecting ewes were CNS (1811; 77 \%), followed by STHAU (513; $21.83 \%$ ) and STR (217; $9.23 \%)$ when only animals were analyzed.

Table 5 shows components of variance due to FlockYear-Season effect, permanent environment effect, additive genetic effect, phenotypic effect and heritabilities for resistance to CNS, STR and ALL. Due to the low frequency of isolation of ESCCL, STHAU, STPDG, STPUB, STPAG, BACIL, CORLT, PASCL, and PSELT in the total records and isolation of pathogens per animals (Tables 3 and 4), problems associated with convergence were found when analyzing resistance to these bacteria. In contrast, there was statistically significant genetic

Table 3 Absolute (AF) and relative (RF) frequency distribution according to udder status of observations $(n=20,519)$

\begin{tabular}{llll}
\hline Pathogen & Status $^{{ }^{a}}$ & AF & RF \\
\hline CNS & 0 & 12,568 & 0.61 \\
& 1 & 7951 & 0.39 \\
STHAU & 0 & 19,579 & 0.95 \\
& 1 & 940 & 0.05 \\
STR & 0 & 19,978 & 0.97 \\
& 1 & 541 & 0.03 \\
ALL & 0 & 13,246 & 0.62 \\
& 1 & 8019 & 0.38 \\
\hline
\end{tabular}

CNS coagulase-negative staphylococci, STHAU Staphylococcus aureus, STR streptococci, ALL observed bacteriological colonies as described in M\&M section

${ }^{\text {a }}$ Udder status as binary record: $0=$ not infected, $1=$ infected 
Table 4 Absolute (AF) and relative (RF) frequency distribution according to udder status of animals $(n=2350)$ per pathogen

\begin{tabular}{llll}
\hline Pathogen & Status $^{a}$ & AF & RF \\
\hline CNS & 0 & 539 & 0.23 \\
& 1 & 1811 & 0.77 \\
STHAU & 0 & 1837 & 0.78 \\
& 1 & 513 & 0.22 \\
STR & 0 & 2133 & 0.91 \\
& 1 & 217 & 0.09 \\
ALL & 0 & 612 & 0.26 \\
& 1 & 1738 & 0.74 \\
\hline
\end{tabular}

CNS coagulase-negative staphylococci, STHAU Staphylococcus aureus, STR streptococci, ALL observed bacteriological colonies as described in M\&M section

a Udder status as binary record: $0=$ not infected, $1=$ infected

variation for CNS, STR, and ALL pathogens (Table 5). Variances due to FYS random effect were 0.18, 0.09 and 0.79 , whereas due to permanent environment effect were $0.39,0.39$, and 0.40 for CNS, STR and ALL, respectively. Variances of additive and phenotypic effects were 0.03 , 0.15, 0.04; and 1.60, 1.62, 2.23, for CNS, STR and ALL, respectively. The heritability obtained for STR (0.09) was significant different from zero, whereas for CNS (0.02) and ALL (0.02) were not.

Table 6 shows phenotypic and genetic correlations for resistance to mastitis caused by STR, CNS and ALL estimated using a multivariate repeatability linear model. All of the estimated phenotypic and genetic correlations were significantly different from zero. The phenotypic correlation between ALL and STR was low, however, the genetic correlation between these traits was moderately high indicating that there was a direct relationship between these traits in genetic terms. On the other hand, both phenotypic and genetic correlations between ALL and CNS were high, indicating that there was a strong positive relationship, both phenotypic and genetic, between these traits. These results suggest that resistance to CNS is a similar to the resistance when it is measured as ALL. In addition, the phenotypic correlation between STR and CNS was negative and the genetic correlation between these traits was low, thus, indicating that selection for improved STR will not have an impact on CNS resistance.

\section{Discussion}

The overall infection prevalence considering frequency of infection on all the samples of records was $37.7 \%$, close to the value of $42 \%$ reported in a previous investigation in the same breed [25], and higher than the values of 26.2 and $24.6 \%$ reported by Pengov [15] and Gonzalo et al. [16], respectively. However, in the study of Pengov [15] only one milk sample ( $n=496$ samples, 251 ewes) of udder halves was considered, whereas the study of Gonzalo et al. [16] was based only on subclinical mastitis prevalence. When the prevalence was assessed on all the animals it increased to $74 \%$, higher than any prevalence reported in previous studies.

Probably the high SCC reported in our study are a consequence of inadequate preventive management, a lack of strict hygiene conditions and extensive management practices, generating a high number of subclinical mastitis cases due to environmental pathogens. Moreover, our results suggested that ewes have higher SCC than cows and it is therefore necessary to establish an acceptable threshold in dairy sheep considering the difference in SCC between breeds and other factors [15, 18, 22].

Leitner et al. [9] suggested categories for classification of SCC in sheep and goat related to quality of milk and infection status. These researchers suggested that infection of 25, 50 and $75 \%$ of the udders in a given herd was associated with 4.1 to $12.2 \%$ of milk loss in sheep and 0.8 to $2.3 \%$ in goats [9]. Mavrogenis et al. [30] suggested that an increase of 0.5 cells $/ \mathrm{mL} \times 10^{6} \mathrm{SCC}$ above the mean resulted in reduction of mean individual daily production of milk by $18 \mathrm{~g}$.

In the present study, there was a $68 \mathrm{~g}$ difference in mean MY between infected and non- infected ewes. For $\mathrm{SCC}$, the mean value for infected animals was approximately 3-fold higher than uninfected animals, similar to values reported in a previous study [24]. However mean SCC for healthy animals were different. Mean SCC for uninfected animals was different to the value of 89 cells/ $\mathrm{mL} \times 10^{3}$ reported by Pengov [15] and 311 cells $/ \mathrm{mL} \times$ $10^{3}$ reported by Leitner et al. [4], and similar to the value of 1490 cells $/ \mathrm{mL} \times 10^{3}$ reported by Kern et al. [31]. These studies focused on Domestic Highland, East Friesand, and Awassi breeds, including their crosses and the Assaf breed, respectively. Moreover, considering the whole data set, mean SCC for infected animals was

Table 5 Estimates of components of variance and their standard errors for infectious status

\begin{tabular}{llllll}
\hline $\begin{array}{l}\text { Resistance Trait } \\
\text { Infection Status }\end{array}$ & $\boldsymbol{\sigma}_{\text {FYs }}^{2}$ & $\boldsymbol{\sigma}_{\mathrm{PE}}^{2}$ & $\boldsymbol{\sigma}_{\mathbf{a}}^{2}$ & $\boldsymbol{\sigma}_{\boldsymbol{P}}^{2}$ & $h^{2}$ \\
\hline ALL & $0.79 \pm 0.17$ & $0.40 \pm 0.03$ & $0.04 \pm 0.02$ & $2.23 \pm 0.17$ & $0.02 \pm 0.01$ \\
CNS & $0.18 \pm 0.04$ & $0.39 \pm 0.03$ & $0.03 \pm 0.02$ & $1.60 \pm 0.05$ & $0.02 \pm 0.01$ \\
STR & $0.09 \pm 0.03$ & $0.39 \pm 0.07$ & $0.15 \pm 0.07$ & $1.62 \pm 0.05$ & $0.09 \pm 0.04$
\end{tabular}

$\sigma_{F Y S}^{2}$ Flock-Year-Season effect, $\sigma_{P E}^{2}$ permanent environment effect, $\sigma_{a}^{2}$ ) additive genetic effect, $\sigma_{P}^{2}$ phenotypic effect, $h^{2}$ heritabilities

CNS coagulase-negative staphylococci, STR streptococci, ALL observed bacteriological colonies as described in M\&M section 
Table 6 Phenotypic (above diagonal) and genetic (below diagonal) correlations and standard errors for resistance to mastitis

\begin{tabular}{llll}
\hline Infection status & STR & CNS & ALL \\
\hline STR & - & $-0.08 \pm 0.02$ & $0.17 \pm 0.01$ \\
CNS & $0.24 \pm 0.25$ & - & $0.87 \pm 0.01$ \\
ALL & $0.36 \pm 0.22$ & $0.92 \pm 0.04$ & - \\
\hline
\end{tabular}

CNS coagulase-negative staphylococci, STR streptococci, ALL observed bacteriological colonies as described in M\&M section

similar to reported values in the literature [4, 24]. Mean SCS for uninfected and mean SCS of whole data set were similar to the values reported in Valle del Belice $[24,25]$, and Churra dairy sheep breeds [32]. For mean SCS of infected animals, Riggio et al. [24] reported a value of 6.42 and Leitner et al. [33] a value of 6.32 in Israel-Assaf and Awassi sheep, similar to the value of 6.21 obtained in our research. Another study reported lower values of mean SCS of infected animals using different breeds [32].

Our study confirms that CNS is the most prevalent etiological group of bacteria in the infected dairy ewes. The frequency of isolation of CNS on record (39 \%) was lower than other studies ranging from 60 to $90 \%$ [3, 24, 32, 34-36]. Moreover, a high percentage (77\%) of animals were found infected at least one or more times in the period of study, showing the importance of this group of bacteria in this population.

Most cases of CNS infection produce subclinical mastitis, although intramammary infections in its subclinical form by CNS have been described as the main single factor affecting udder health and profitability in small ruminants [9]. Besides, due to the high prevalence of CNS during the ewe's lactations, subclinical cases could persist, significantly increase SCC and consequently cause clinical mastitis. This is a possible explanation of the observed differences of SCC between infected and non-infected animals and frequency of animals infected by CNS. Moreover, considering the opportunistic nature of CNS [17], with adequate hygiene practices, correct milking routine and periodic revision of milking equipment, intramammary infections by CNS could be reduced.

In this investigation, CNS were classified as minor pathogens. Researchers have reported that some species of CNS can cause high SCC, similar to those of major pathogens [15, 32, 37] and even clinical mastitis [32, 38]. Ariznabarreta et al. [32] described that Staphylococcus caprae and S. simulans were associated with high log SCC, 6.43 and 6.35, respectively, in contrast with other CNS bacteria such as S. chromogenes, S. hominis, S. capitis, S. haemolyticus and S. epidermidis ranging from 5.93 to 6.09 . Therefore, there was variation in the inflammatory response according to the involved CNS species and their pathogenicity in milk measured through SCC, even on average ten times higher than in dairy cattle [15]. STHAU was the second one more frequently isolated bacteria in our study (5\%) followed by STR (3\%). This order differs from other authors, which reported that CNS is the most prevalent group of bacteria followed by STR [15, 31, 35, 38]. For STHAU, ewes infected at least one time or more in the period of study were $22 \%$ (513). These findings are different respect to what reported by Riggio et al. [24] with values of $10.47 \%$ of milk samples and similar to other studies ranging from 2 to $5.5 \%[15,32]$. Infection due to STHAU is related with subclinical to acute clinical mastitis (gangrenous mastitis) with different clinical symptoms according to the virulence of the strains and in severe cases lead towards culling of the affected sheep [2, 17]. The high percentage of animals affected by STHAU in the period of study could be related with clinical mastitis cases and culling of ewes in this population. This was in agreement with Mavrogenis et al. [30] which identified STHAU as the most prevalent bacteria in clinical mastitis cases.

In sheep a heritability estimate of 0.09 for infection status assessed by bacteriological analyses was reported by Riggio et al. [24] and Tolone et al. [25] in the Valle del Belice breed using a threshold animal model assuming a probit link function. Gonzalo et al. [39] estimated genetic parameters of SCC in Churra sheep considering the type of mammary pathogen using a multitrait repeatability animal model. They reported that the effect related to the type of pathogen accounted for $32.5 \%$ of the total variance in SCC, a value similar to that obtained for the residual effect (34.9\%), indicating a high relative importance of the type of pathogen in the decomposition of the variance for SCC. In addition, Holmberg et al. [40] in dairy cattle reported genetic variances for different pathogens ranging from 0.024 to 0.188 , similar to the values of the present research $(0.03$ to 0.15). These results showed the importance of differentiating between the types of mammary bacteria assessed by bacteriological analyses in genetic mastitis studies.

Variances due to permanent environment and FYS effects were high and were important factors to explain the phenotypic variance resistance against CNS, STR and ALL. The possible explanations of these results for CNS group of pathogens are their nature and their high frequency of isolation in this sheep breed. CNS group of bacteria are related with inadequate management and hygiene practices, which could be different among the flocks, through the year and among them. Therefore, due to opportunistic nature of CNS, poor flock management and inadequate milking hygiene could increase the probability of occurrence of mastitis, and flocks may act as reservoirs of some CNS species. Taking into account the 
predominant sheep husbandry system in Sicily based on grazing with animals kept outdoors, reductions in pasture quantity and quality through the year as in summer (peak of lambing in Valle del Belice sheep) could be a stress factor to increase the susceptibility due to ALL infection. High temperatures in summer are associated with heat stress [8], and as occurs in dairy cattle heat stress is recognized as a factor which increases susceptibility to mastitis. Gonzalo et al. [41] reported that month within flock and flocks were accounted $44.1 \%$ of the variance on bulk tank bacteria count, whereas Portolano et al. [8] reported that flock-year of lambing effect explains $27 \%$ of the variance of time interval between lambing and first record with mastitis.

Heritabilities for pathogen-specific mastitis were in agreement with results of De Haas [20] in dairy cattle ranging from 0.02 to 0.10 . However, this study only included heritabilities of pathogens involved in clinical mastitis cases and were estimated through threshold and linear models. For genetic correlations, the one estimated between CNS and ALL (0.92) was positive and very high suggesting that both are the same traits. This could be explained for the high frequency of isolation of CNS in the records (77\%). Thus, a high percentage of ALL group is explained by CNS pathogens. Furthermore, due to the fact that phenotypic variation for CNS and ALL is determined primarily by an environmental component both type of traits (CNS and ALL) could be controlled more effectively by applying a correct management measures instead of selective breeding on these population.

In the Valle del Belice breed, where the current selection is mainly practiced on a "within farm" approach and based on own performance of ewes, it is unlikely that selection for mastitis resistance is successful, independent of the use of infection status or SCS.

\section{Conclusions}

The results of our study support the presence of significant genetic variation for resistance to one specific pathogen causing mastitis (i.e. Streptococci). The high genetic correlation between ALL and CNS indicate that both are almost the same trait. The opportunistic nature of CNS and the high environmental influence of CNS resistance suggest that improvement of flock management and adequate milking hygiene could reduce significantly the incidence of mastitis caused by this pathogen in Valle del Belice dairy sheep.

\footnotetext{
Abbreviations

A, animal; AF, absolute frequency; $A L L$, all pathogens together; $B A C I L$, Bacillus spp.; CFU, five colony forming units; CNS, coagulase-negative staphylococci; CORLT, Corynebacterium spp.; ESCCL, Escherichia coli; FYS, flock year season; MY, milk yield; OP, order of parity; PASCL, Pasteurella spp.; PE, permanent environmental; PSELT, Pseudomonas spp.; RF, relative frequency; SCC, somatic cell count; SCS, somatic cell score; STHAU, Staphylococcus aureus; STPAG, Streptococcus agalactiae; STPDG, Streptococcus dysgalactiae; STPUB, Streptococcus uberis; STR, Streptococci; STR, Streptococcus spp
}

\section{Acknowledgements}

We acknowledge Dr. M.L Scatassa (Istituto Zooprofilattico Sperimentale della Sicilia) for bacteriological analyses.

\section{Funding}

No funding was obtained for this study.

\section{Availability of data and materials}

The data and pedigree supporting our findings are publicly available online at https://figshare.com/articles/data_txt/3467942 and https://figshare.com/ articles/pedigree_txt/3467945, respectively.

\section{Authors' contributions}

$\mathrm{MT}$ and $\mathrm{CL}$ contributed equally to this work, they carried out the design of the study, performed statistical analysis and drafted the manuscript. JMY participated in statistical analysis and drafted the manuscript. SN helped to draft the manuscript and to interpret the results. MTS helped to collect the data and revised critically the manuscript. BP participated in the design of the study and gave the final approval of the version to be submitted. All authors read and approved the final manuscript.

\section{Competing interests}

The authors declare that they have no competing interests.

\section{Consent for publication}

Not applicable

\section{Ethics approval and consent to participate}

The milk samples were collected during routine milking so avoiding any harmful process to individuals. The milking procedure followed the A4 recording scheme which is defined by the International Committee for Animal Recording (ICAR, 2014). The consent for sample collection was obtained by the animals' owners. Moreover, Sample collection, animal management and cares were in agreement with the Directive 2010/63/EU.

\section{Author details}

'Dipartimento Scienze Agrarie e Forestali, Università degli Studi di Palermo, Viale delle Scienze, Palermo 90128, Italy. ${ }^{2}$ Faculty of Veterinary and Animal Sciences, University of Chile, Av. Santa Rosa, La Pintana, Santiago 11735, Chile. ${ }^{3}$ Genus plc, Hendersonville, TN 37075, USA.

Received: 24 October 2015 Accepted: 20 July 2016

Published online: 28 July 2016

\section{References}

1. Barillet F, Rupp R, Mignon-Grasteau S, Astruc JM, Jacquin M. Genetic analysis of mastitis resistance and somatic cell score in French Lacaune dairy sheep. Genet Sel Evol. 2001;33:397-415.

2. Leitner G, Chaffera M, Zamirb S, Mora T, Glickmana A, Winklera M, Weisblita M, Sarana A. Udder disease etiology, milk somatic cell counts and NAGase activity in Israeli Assaf sheep throughout lactation. Small Rumin Res. 2001; 39:107-12.

3. Bergonier D, Cremoux R, Rupp R, Lagriffoul G, Berthelot X. Mastitis of dairy small ruminants. Vet Res. 2003;34:689-716.

4. Leitner G, Chaffer M, Shamay A, Shapiro F, Merin U, Ezra E, Saran A, Silanikove N. Changes in milk composition as affected by subclinical mastitis in sheep. J Dairy Sci. 2004;87:46-52.

5. Carlén E, Schneider M, Strandberg E. Survival analysis for genetic evaluation of mastitis in Dairy Cattle: A simulation study. J Dairy Sci. 2005;88:797-803.

6. Barillet F. Genetic improvement for dairy production in sheep and goats. Small Rumin Res. 2007;70:60-75.

7. Legarra A, Ramon M, Ugarte E, Perez-Guzman MD, Arranz J. Economic weights of somatic cell score in dairy sheep. Animal. 2007;1:205-12.

8. Portolano B, Finocchiaro R, Van Kaam J, Riggio V, Maizon DO. Time-to-event analysis of mastitis at first-lactation in Valle del Belice ewes. Livest Sci. 2007; 110:273-9.

9. Leitner G, Silanikove N, Merin U. Estimate of milk and curd yield loss of sheep and goats with intramammary infection and its relation to somatic cell count. Small Rumin Res. 2008;74:221-5. 
10. Riggio V, Maizon D, Portolano B, Bovenhuis H, van Arendonk J. Effect of somatic cell count level on functional longevity in Valle del Belice dairy sheep assessed using survival analysis. J Dairy Sci. 2009;92:6160-6.

11. Rupp R, Boichard D. Genetics of resistance to mastitis in dairy cattle. Vet Res. 2003;34:671-88.

12. Rupp R, Foucras G. Genetics of mastitis in dairy ruminants. In: Breeding of disease resistance in farm animals. 2010. p. 183-212.

13. Rupp R, Bergonier D, Dion S, Hygoneng MC, Aurel MR, Robert-Granie C, Foucras $\mathrm{G}$. Response to somatic cell count-based selection for mastitis resistance in a divergent selection experiment in sheep. J Dairy Sci. 2009;92:1203-19.

14. Smith K, Hogan J. The world of mastitis 2nd International Symposium on mastitis and milk quality. Canada: Vancouver; 2001.

15. Pengov A. The role of coagulase-negative Staphylococcus spp and associated somatic cell counts in the ovine mammary gland. J Dairy Sci. 2001;84:572-4

16. Gonzalo C, Ariznabarreta A, Carriedo J, San Primitivo F. Mammary pathogens and their relationship to somatic cell count and milk yield losses in dairy ewes. J Dairy Sci. 2002;85:1460-7.

17. Contreras A, Sierra D, Sánchez A, Corrales JC, Marco JC, Paape MJ, Gonzalo C. Mastitis in small ruminants. Small Rumin Res. 2007:68:145-53.

18. Riggio V, Portolano B. Genetic selection for reduced Somatic Cell Counts in sheep milk: A review. Small Rumin Res. 2015;126(1):33-42.

19. White LJ, Schukken YH, Lam TJG, Medley GF, Chappell MJ. A multispecies model for the transmission and control of mastitis in dairy cows. Epidemiol Infect. 2001;127:567-76.

20. De Haas Y. Somatic cell count patterns Improvement of udder health by genetics and management. Wageningen, NL: PhD Thesis, Wageningen University; 2003

21. De la Cruz M, Serrano E, Montoro V, Marco J, Romeo M, Baselga R, Albizu J, Amorena B. Etiology and prevalence of subclinical mastitis in the Manchega sheep at mid-late lactation. Small Rumin Res. 1994;14:2175-180.

22. Tolone M, Riggio V, Portolano B. Estimation of genetic and phenotypic parameters for bacteriological status of the udder, somatic cell score, and milk yield in dairy sheep using a threshold animal model. Livest Sci. 2013; 151:134-9.

23. Riggio V, Pesce LL, Morreale S, Portolano B. Receiver-operating characteristic curves for somatic cell scores and California mastitis test in Valle del Belice dairy sheep. Vet J. 2013;196:528-32.

24. Maurer J, Schaeren W. Udder health and somatic cell counts in ewes. Agrarforschung. 2007;14:162-7.

25. Riggio V, Portolano B, Bovenhuis H, Bishop S. Genetic parameters for somatic cell score according to udder infection status in Valle del Belice dairy sheep and impact of imperfect diagnosis of infection. Gen Sel Evol. 2010;42:30.

26. Heringstad B, Klemetsdal G, Steine T. Selection responses for clinical mastitis and protein yield in two norwegian dairy cattle selection experiments. J Dairy Sci. 2003:86:2990-9.

27. ICAR (International Committee for Animal Recording), 2014. International agreement of recording practices. Available online: http://www.icar.org/ index.php/publications-technicalmaterials/recording-guidelines/ 2014.

28. Gilmour AR, Gogel BJ, Cullis BR, Thompson R. ASReml User Guide Release 3. 0 VSN International Ltd, Hemel Hempstead, HP1 1ES, UK www.vsni.co.uk. 2009;

29. Ali A, Shook G. An optimum transformation for somatic cell count in milk. J Dairy Sci. 1980;63:487-90

30. Mavrogenis A, Koumas A, Kakoyiannis C, Taliotis C. Use of somatic cell counts for the detection of subclinical mastitis in sheep. Small Rumin Res. 1995; 17:79-84

31. Kern G, Traulsen I, Kemper N, Krieter J. Analysis of somatic cell counts and risk factors associated with occurrence of bacteria in ewes of different primary purposes. Livest Sci. 2013;157:597-604.

32. Ariznabarreta A, Gonzalo C, San Primitivo F. Microbiological quality and somatic cell count of ewe milk with special reference to staphylococci. J Dairy Sci. 2002:85:1370-5

33. Leitner G, Chaffer M, Caraso Y, Ezra E, Kababea D, Winkler M, Glickman A, Saran A. Udder infection and milk somatic cell count, NAGase activity and milk composition-fat, protein and lactose-in Israeli-Assaf and Awassi sheep. Small Rumin Res. 2003:49:157-64

34. Contreras A, Corrales JC, Sierra D, Marco JC. Prevalence and aetiology of non-clinical intramammary infection in Murciano- Granadina goats. Small Rumin Res. 1995;17:71-8.
35. González-Rodríguez MC, Gonzalo C, San Primitivo F, Cármenes P. Relationship between somatic cell count and intramammary infection of the half udder in dairy ewes. J Dairy Sci. 1995;78:2753-9.

36. Las Heras A, Domínguez L, Fernández-Garayzábal J. Prevalence and aetiology of subclinical mastitis in dairy ewes of the Madrid region. Small Rumin Res. 1999:32:21-9.

37. Marco JC. Mastitis en la oveja Latxa: epidemiología, diagnóstico y control. PhD Thesis. España: Universidad de Zaragoza; 1994.

38. Fthenakis GC. Prevalence and aetiology of subclinical mastitis in ewes of Southern Greece. Small Rumin Res. 1994;13:293.

39. Gonzalo C, Ariznabarreta A, Othmane M, Carriedo J, De La Fuente L, San Primitivo F. Genetic parameters of somatic cell count in dairy sheep considering the type of mammary pathogen effect. J Anim Breed Genet 2003;120:282-7.

40. Holmberg M, Fikse WF, Andersson-Eklund L, Artursson K, Lunde A. Genetic analyses of pathogen-specific mastitis. J Anim Breed Genet. 2012;129:129-37.

41. Gonzalo C, Carriedo J, Beneitez E, Juarez M, De La Fuente L, San Primitivo F. Short Communication: bulk tank total bacterial count in dairy sheep: factors of variation and relationship with somatic cell count. J Dairy Sci. 2006:89:549-52

\section{Submit your next manuscript to BioMed Central and we will help you at every step:}

- We accept pre-submission inquiries

- Our selector tool helps you to find the most relevant journal

- We provide round the clock customer support

- Convenient online submission

- Thorough peer review

- Inclusion in PubMed and all major indexing services

- Maximum visibility for your research

Submit your manuscript at www.biomedcentral.com/submit
) Biomed Central 